\title{
The Failure of Home Depot in China - A Case Study
}

\author{
Shihui Zheng \\ Correspondence: Shihui Zheng, Business School, Queensland University, 92E/60 Tribune St, South Brisbane, 4101, \\ QLD, Australia.
}

Received: October 18, 2017

Accepted: November 8, 2017

Online Published: November 12, 2017

doi:10.11114/bms.v3i4.2791

URL: https://doi.org/10.11114/bms.v3i4.2791

\begin{abstract}
In modern business management, organizational behavior is a crucial factor in influencing the success. Especially, when considering the market performance of a business, the decision-making behavior may be an important factor. In different local conditions, organizational behavior might be a determining factor in success. The paper, by studying the case of the US Home Depot in China, attempts to analyze the behavioral factors impacting the success in the local place of its targeted market. Based on the two factors including incompetent local adaptation and the wrong entry time and entry mode leading to failure, some recommendations are made. Firstly, the company could conduct a more detailed and systematic research of the local conditions, especially the local cultural and economic features. Secondly, it is crucially important to know the exact time and the suitable entry mode. Thirdly, that the Home Depot could have study the communicative mode with the locals heavily influenced by the local cultural traditions and conventions in order to avoid blind entry strategy. To conclude, for the success of cross-border businesses, being adaptable to the local consuming habits is an important premise of the sustainable development for the Home Depot in the international market.
\end{abstract}

Keywords: Home Depot, failure, China, organizational behavior

\section{Introduction}

In modern business management, organizational behavior is a crucial factor in influencing the success. Especially, when considering the market performance of a business, the decision-making behavior may be an important factor. In different local conditions, organizational behavior might be an influential factor success (Robbins, 2004). Often, management failure results in improper behaviors such as the misunderstanding of the local needs and the wrong entry strategy (Moorhead \& Griffin, 1995). In addition, the people factor, which is another important element of organization behavior, is as well crucially important in determining the management success. In a narrower sense, organizational behavior (often shortened as OB) refers to what an organization does to influence its performance in its targeted markets. It is often related to an "interface of an organization between human behavior and the organization itself" (Hatch, 2006). Often it includes two levels of behaviors, namely the individual level and the organizational level. The former often refers to the behaviors of the micro level, including the interaction and communication mode among the employees whereas the latter often refers to the behaviors of the macro level including management strategies and leadership style which are crucial in influencing the overall performance of an organization in its targeted market places (Wagner \& Hollenbeck, 2010). On the whole, the organizational behavior as an important management factor directly impacts the success in targeted market places. The paper, by using the example of the US Home Depot in China, tries to analyze the behavioral factors impacting the success in the local place of its targeted market.

\section{Description of the US Home Depot and Its Failure in China}

The Home Depot is a US company targeted at providing home improvement supplies on the international scale. The company operates format stores across the US as well as overseas markets outside the United States. Headquartered in Atlanta, the company is known to be a strong competitor in the home improvement appliance retailing market in the world. So far, it is the largest home improvement retailer in America and is also highly influential in overseas home improvement markets. The company holds the value of "more saving and more doing", focusing on the DIY (do it yourself) style of home improvement experience by its targeted customers. The Home Depot entered the Chinese market in 2006 by acquiring the local improvement business the Home Way in Shanghai. The entrance of the Home Depot quickly gained immediate presence in six major cities in China, marking an important step of the company's development in the international home improvement market (Zimmerman, 2007). The company had a very ambitious 
plan in China but, due to very complicated reasons, the plan has been carried in an ideal way and from 2011, the company gradually closed some major stores in Beijing, Shanghai and other big cities in China. In 2012, all seven of its standardized box stores were shut down in China, implying the failure of its business expansion in China (Bray, 2015).

\section{Issues That Lead to the Failure}

The failure of the Home Depot in China has been attributed to a number of complicated reasons, one of which is the disconnection between the DIY ethos and the specific local culture. In 2012, the company confessed its wrong marketing strategy in China with misleading the country's appetite for DIY products. As a spokeswoman of the company said to the Wall Street Journal in 2012, the Chinese consuming culture is more do-it-for-me rather than do-it-myself. Thus the lack of motivation for the local consumer to accept the DIY service is the major root of its failure in the local settings. To put it in details, the failure of the Home Depot in China could be attributed to the following.

\subsection{Incompetent Local Adaptation}

In modern business management, adaptation to the local conditions is often regarded as a crucially important strategy to be flexibly integrated into the local market according to the specific consuming habits of the local customers (Simms, et al., 1994). The lack of flexibility to the local culture is a fatal element for the Home Depot's failed performance in China. As is known to all, the Chinese are not accustomed or interested in using self-made products because of the national generic reluctance to try something not approved by the vast majority. In the Chinese local culture, people are often reluctant in using products and services which have not been widely accepted; on the contrary, they tend to follow the widely-accepted way of consumption (Miner, 2006), which might attribute itself to "collectivistic orientation" defined as people's tendency to view the self as derived from a specific reference group (e.g., family, friends, relatives) such that their behavior is likely to be under the influence of members of this reference group or important others (Fischer, et al., 2010; Markus \& Kitayama, 1991; Triandis, 1989; Liu, et al., 2011). In light of the definition, consumers in collectivistic oriented cultures highlight the social context and seek to comply with the wishes of important others when making decisions (Harb \& Smith, 2008; Lee \& Green, 1991). In addition, not many home-improvement hobbyists are interested in the do-it-yourself way of consumption of products in China. In the US in these home-improvement hobbyists who are willing to use the aisles of power tools and building materials provided by the Home Depot domestically, the Chinese consumers, on the other hand, are not accustomed to using these utensils. So the wrong perception of the cultural difference between American and Chinese consumers is a major reason for its failure in China.

Cultural strategy is an important business behavior by modern organizations to be successful. By and large, this is a strategy that impacts almost all aspects of employee and customer management in local markets by modern companies (Scott, 2007). The failed endeavor to adapt to the local consuming power is another factor for the Home Depot's marketing behavior in China. To most of the Chinese consumers, the products of the Home Depot are too expensive to be accepted. The failure in fact lies in the misreading of the local consumers who focus more on inexpensive home improvement products and services instead of the higher-end products provided by the Home Depot. To them the company's products and services are too expensive. This is a factor directly leading to the failed marketing behavior of the Home Depot in the local market of the major cities in China.

The incapability of dealing with various social relationships (in Chinese "Guanxi") is also a fatal problem of the company's local management. In the Chinese culture, the Guanxi is so important a concept that it has profound influence on marketing performances in market entry and international expansion (Chen, et al., 2013). For Home Depot, though the company has focused on the improvement of the customer relationship by providing different types of self experiencing services, it has neglected dealing with the relations with the local officials, who are believed to have decisive powers which are important for a business to develop continually in China. Thus for the Home Depot, this failed management behavior has resulted in the disadvantageous position of the company in the local market competition, finally led to the shrunk market share in China.

\subsection{The Wrong Entry Time and Entry Mode}

Knowing the local customer needs is essentially important to the section of suitable time and entry mode by modern organizations (Jex \& Britt, 2008). However, for the US Home Depot, this is another crucially fatal factor for its entry into China. First, the choice of the wrong time when its major business competitors have been well-established in China is a fatal mistake by the company. Take the Swedish IKEA for example, as one of the world's largest home improvement companies, IKEA has been highly successful in occupying the home improvement market and has especially been efficient in attracting the local customers with its cheap products suitable for the comparatively lower consuming capacity of the locals. Also in the local settings, numerous home improvement businesses with the convenience of use the local resources (including both human resources and local raw materials) to cut short the management expenses. As a result, from the very beginning the Home Depot has been in the disadvantageous position 
of market competition compared with its major competitors.

This wrong entry strategy is also reflected in the company's misreading of the local people to buy homes. In China for the time being, many people do not buy houses for living themselves. On the contrary, they buy homes as an opportunity of investment. As a result, they do not include home improvement in their investment plan. Often, when a home has been improved and decorated, it does not sell well. Also, to most people in China, DIY is a time-consuming and complicated job. They are reluctant to accept such a service which needs personal initiatives. Instead, they tend to accept services provided by others. Most Chinese consumers prefer to see a finished product rather than do the detailed time-consuming job by themselves (Smith, 2008). As a result, just as what has been said by a spokesman of the Home Depot when talking to the Wall Street Journal, China is a "do-it-for-me market" rather than a "do-it-yourself market". In such a market, the Home Depot could not be as successful in China than at home in the US.

The wrong entry mode as well results in the failed investigation of the customer segmentation in China is another incompetent customer communication by the Home Depot in China. Upon the entrance of the Home Depot in China, the marketing plan was much a product of self assumption of the possible performance of the company in the local market in China. It lacks of the detailed research of the consuming behavior and market feature of the Chinese local conditions. For example, the company has only seen the potential developmental opportunity in China because of the dense population in some of the major cities but has neglected the sustainability of the company's DIY mode of services in China. Anyway, the plan of the company should have to be based on a solid investigation of the consuming habits of the locals (Baron \& Greenberg, 2008). However, for the company, it has taken for granted the chances of success without any in-depth analysis of the local needs which finally led to the management failure of the company in China.

\section{Evaluation of Organizational Response}

Having realized its failed marketing in China, the Home Depot quickly responded to the wrong strategy. The company shut down all the standard box DIY stores in China in 2012 and began to retreat from the local market. From this failure the company has summarized the reasons for the wrong marketing strategy by focusing on the incompetent cultural strategy of the company in the local settings. For Home Depot, it has realized that the incompetent customer communication is a major reason for its failure in China. This failure, to a large extent, is generated from the very difference from the Chinese culture and American culture at large. According to Hofsted's model of Cultural Dimensions, people of different nations have shown different tendencies of cultural preferences according to the local cultural traditions (Hofstede \& Bond, 1984; 1988; Hofstede,1991). Here the difference in uncertainty avoidance index, the indulgence vs restraint index and the individualism vs collective index between the US and China could be seen as the major misunderstandings by the Home Depot in China.

The company has also realized the wrong understanding of the indulgence vs. restraint index which, according to Hofsted, refers to the cultural dimension of the measurement of personal happiness by people of different nations. In Hofsted's model of cultural dimensions, this dimension essentially implies whether or not simple joys could be effectively fulfilled by what people do in their daily life. Indulgence usually refers to the cultural aspect of a nation that allows free gratification of human desires to enjoy the funs in life; whereas restraint refers to the cultural aspects of people in nations in which people such a gratification is controlled by strict social norms (McSweeney, (2002). In the home country of the Home Depot, the United States, it belongs to the former type of society in which people often enjoys the funs of doing things for themselves but in China, which is a more restrained society, there are social norms restricting this initiative. Therefore for most of the Chinese locals, they do not like to behave differently from others whereas in America, people often value this initiative very much. This difference has led to the failure of the DIT mode of services by the Home Depot in China.

The Home Depot has as well responded to the misunderstanding of the uncertainty avoidance index in China, which is defined as a society's tolerance for ambiguity. In the United States, people have the tendency of embracing an event unexpected or unknown. Thus they are willing to take adventurous actions in their life including consumption. However, in China and other Oriental societies, the index of uncertainty avoidance is higher than that of the US, implying the local people in China have stiff codes of behavior and social conventions. Considering this difference, the American people are more willing to accept the uncertainty of the DIY services while the Chinese people are more reluctant to accept the higher degree of uncertainty of the DIY products and services provided by the Home Depot.

The fourth reason summarized by the company is the misunderstanding of the individualism vs collectivism index in the US and China. To the Americans, individualism is a key word to understand the American culture, in which people are often interested in risky and adventurous actions of doing things. To put it another way, the Americans are more interested in doing things from their own personal experience of curiosity and newness (Triandis, 1995). In the behavior of product or service consumption, this is also a deeply-rooted national habit. As a result, to most American people, the DIY way of doing things may give them such experience. However, in China collectivism is a dominant cultural aspect 
which is essentially to limit the initiative of curiosity to try something new in life (Alvesson \& Deetz, 2006). To most Chinese consumers, they lack such an initiative in buying consuming goods or services which are uncertain and out of the collective expectation of the vast majority. Usually they are more willing to accept products and services which have already finished for convenient use. Thus the Home depot has realized that the different consuming habit of the Chinese locals is one of the major roots of the failure.

\section{Recommendations}

To summarize, the failure of the US Home Depot in China has revealed the fact that a modern company has to be flexible in understanding the local needs of the targeted market places on the global scale of business management. For its future cross-border marketing, it is recommended that the company could have conducted a more detailed and systematic research of the local conditions, especially the local cultural and economic features which are crucial in impacting the motivation of consumption of the locals. Also, to know the exact time and the suitable entry mode is as well crucially important. In the third place, it is as well recommended that the Home Depot could have studied the communicative mode with the locals who have been heavily influenced by the local cultural traditions and conventions in order to avoid blind entry strategy. On the whole, for the success of cross-border businesses, being adaptable to the local consuming habits is an important premise of the sustainable development for the Home Depot in the international market.

\section{References}

Alvesson, M., \& Deetz, S. (2006). Critical theory and Postmodernism approaches to organizational studies. In S. Clegg, C. Hardy, T. Lawrence, W. Nord (Eds.). The Sage Handbook of Organization Studies (2nd ed). London: Sage. https://doi.org/10.4135/9781848608030.n8

Baron, R. A., \& Greenberg, J. (2008). Behavior in organizations. New Jersey: Pearson Education Inc.

Bray, C. (2015). Home Depot to Buy Interline Brands for \$1.6 Billion in Cash. New York Times. Retrieved July 22, 2015.

Chen, C. C., Chen, X. P., \& Huang, S. (2013). Chinese guanxi: an integrative review and new directions for future research. Management \& Organization Review, 9(1), 167-207. https://doi.org/10.1111/more.12010

Fischer, R., Vauclair, C. M., Fontaine, R. J., \& Schwartz, S. H. (2010). Are individual-level and country - level value structures different? Testing Hofstede's legacy with the Schwartz value survey. Journal of Cross-Cultural Psychology, 41(2), 135-151. https://doi.org/10.1177/0022022109354377

Harb, C., \& Smith, P. B. (2008). Self-construals across cultures: Beyond independence interdependence. Journal of Cross-Cultural Psychology, 39(2), 178-197. https://doi.org/10.1177/0022022107313861

Hatch, M. J. (2006). Organization theory: Modern, symbolic, and postmodern perspectives, Oxford: Oxford University Press.

Hofstede, G. (1991). Cultures and Organizations: Software of the Mind. London, UK: McGraw-Hill.

Hofstede, G., \& Bond, M. H. (1984). Hofstede's culture dimensions an independent validation using Rokeach's value survey. Journal of Cross-Cultural Psychology, 15, 417-433. https://doi.org/10.1177/0022002184015004003

Hofstede, G., \& Bond, M. H. (1988). The Confucius connection: from cultural roots to economic growth. Organizational Dynamics, 16, 4-21. https://doi.org/10.1016/0090-2616(88)90009-5

Jex, S., \& Britt, T. (2008). Organizational psychology: A scientist-practitioner approach. New York: Wiley.

Lee, C., \& Green, R. T. (1991). Cross-cultural examination of the Fishbein behavioral intentions model. Journal of International Business Studies, 21(2), 289-305. https://doi.org/10.1057/palgrave.jibs.8490304

Liu, S., Smith, J. R., Liesch, P. W., Gallois, C., Ren, Y., \& Daly, S. (2011). Through the lenses of culture: chinese consumers' intentions to purchase imported products. Journal of Cross-Cultural Psychology, 42(7), 1237-1250. https://doi.org/10.1177/0022022110383315

Markus, H. R., \& Kitayama, S. (1991). Culture and the self: Implications for cognition, emotion, and moti - vation. Psychological Review, 98(2), 224-253. https://doi.org/10.1037/0033-295X.98.2.224

McSweeney, B. (2002). The essentials of scholarship: A reply to Hofstede' human relations, New York: Sage.

Miner, J. B. (2006). Organizational behavior, Vol. 3: Historical origins, theoretical foundations, and the future. Armonk, NY and London: M.E. Sharpe.

Moorhead, G., \& Griffin, R. W. (1995). Organizational behavior: Managing people and organizations (5th edition). Boston. Houghton Mifflin, (p.4). 
Robbins, S. P. (2004). Organizational behavior: Concepts, controversies, applications. New York: Prentice Hall.

Scott, W. R. (2007). Organizations and organizing: Rational, natural, and open systems perspectives. New York: Pearson Prentice Hall.

Simms, L. M., Price, S. A., \& Ervin, N. E. (1994). The professional practice of nursing administration. Albany, NY: Delmar Publishers.

Smith, P. (2008). Indigenous aspects of management. In P. Smith, Peterson, M., Thomas, D. (Eds.), The Handbook of cross-cultural management research. Sage, Thousand Oaks CA: Sage. https://doi.org/10.4135/9781412982764.n19

Triandis, H. C. (1989). The self and social behavior in differing cultural contexts. Psychological Review, 96, 506-520. https://doi.org/10.1037/0033-295X.96.3.506

Triandis, H. C. (1995). Individualism and collectivism. Boulder CO: Westview Press.

Wagner, J. A., \& Hollenbeck, J. R. (2010). Organizational behavior: Securing competitive advantage. New York: Routledge.

Zimmerman, A. (2007). Home Depot Boosts Buyback, Sets Unit Sale. Wall Street Journal. Retrieved August 5 , 2016.

\section{Copyrights}

Copyright for this article is retained by the author(s), with first publication rights granted to the journal.

This is an open-access article distributed under the terms and conditions of the Creative Commons Attribution license which permits unrestricted use, distribution, and reproduction in any medium, provided the original work is properly cited. 